\title{
The Suffering of Arts Entrepreneurs: Will Fine Art Students be Educated on How to Become Successfully Self-Employed?
}

\author{
Marco Thom \\ Correspondence: Marco Thom, London South Bank University, Business Faculty, UK
}

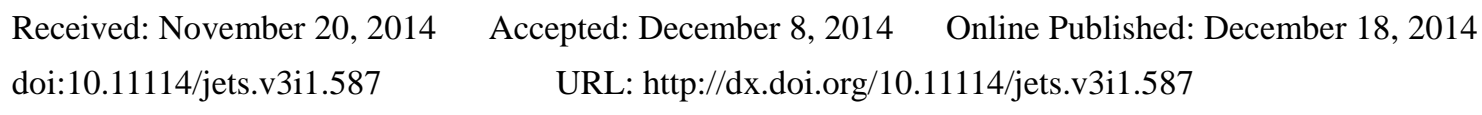

\begin{abstract}
The aim of the study is to show whether, how and to what extent fine art students will be equipped with entrepreneurial skills and therefore be educated on how to make a living as a practicing artist. A comprehensive and comparative analysis of Fine Art degree programmes and extra-curricular training offerings at higher education institutions (HEIs) in the UK and Germany was carried out. By using various key performance indicators this study shows evidence that the crucial entrepreneurial skills for a successful self-employment in the arts are only taught to a very small extent if even at all.
\end{abstract}

Keywords: fine art students, entrepreneurial skills, higher educational institutions, self-employment

\section{Introduction}

\subsection{Background for the Research}

The background to this study is the fact that there are hardly any jobs in the arts available, only opportunities. Recent labour market statistics in the UK and Germany show clear evidence that up to $90 \%$ of fine artists, including painters and photographers are self-employed and mostly organised as one-man-businesses (Statistisches Bundesamt, 2010; Artists Interaction and Representation, 2011; Arts Council England, 2011; Bundesverband Bildender Künstlerinnen und Künstler, 2011; Centre for Economics and Business Research, 2013). They need to successfully meet the multi-facetted commercial and business-related challenges in order to make a living in the arts. In this context they are required to develop entrepreneurial skills to operate like an entrepreneur (Schumpeter, 2003; Swedberg, 2006).

Basically, there are two pathways available for fine artists to develop entrepreneurial skills: on the one hand through organised and supervised trainings, for example, degree programmes at higher educational institutions (HEIs) and on the other hand, more autodidactically, through 'learning by doing' in everyday life as a practicing artist. Considering this, the study focuses firstly on the identification of the entrepreneurial skills which are crucial for fine artists' success in the arts and secondly on the analysis of organised and supervised fine art degree programmes and extra-curricula training offerings at HEIs, particularly in the UK and Germany in order to answer the research question whether fine artists will be equipped during their studies with the required skills. The availability of entrepreneurship education is becoming a factor in the choice and long-term reputation of HEIs as fine art students increasingly demand training that helps them create a successful arts-based career after graduation (Abbing, 1999; de Monthoux, 2004; Weinhold, 2005; Bauer, et al., 2011; Beckman, 2011; Cobb et al., 2011).

\subsection{Literature Review}

A comprehensive review of the literature reveals a variety of models to explain the different factors (including skills) of entrepreneurial success. However, there is still no consensus of what skills are really crucial. Considering the fact that the crucial skills particularly for fine artists' success in the arts have not been identified in the literature, recent studies on the reasons of business failure and entrepreneurial success in other, similar professions to fine art such as journalism or farming, which also face an intense 'winner-takes-all' competition of self-employed individuals (Frank \& Cook, 1996) are used for this study. They provide valuable findings to derive the crucial skills for fine artists' entrepreneurial success. These studies show evidence that the following seven skills can be considered as particularly important for self-employed professionals in an intense competitive market environment (Gibb, 1998; Faltin, 2001, 2007, 2008; Schumpeter, 2003; DeTienne \& Chandler, 2004; Landwehr, 2005; Smith \& Perks, 2006; de Wolf \& Schoorlemmer, 2007; Oberschachtsiek, 2008; Rudmann, 2008; Vesala \& Pyysiainen, 2008; Baines \& Kennedy, 2010; NBIA, 2010; Stokes \& Wilson, 2010; Cobb et al., 2011): 
1) idea development skills,

2) opportunity recognition and realization skills,

3) networking skills,

4) leadership skills,

5) strategic thinking (planning) skills,

6) sales (marketing and promotion) skills, and

7) finance (cash management and funding) skills.

According to de Wolf \& Schoorlemmer (2007), only the first five skills have explicitly and primarily to do with the creating of a successful and profit making business and are considered as pure entrepreneurial skills, while the last two skills of sales/marketing and finance/funding are particularly considered as the most important business management skills, enabling the successful running of the business. In addition, the first five skills are much more complex and of higher quality because they include other skills in contrast to professional, employability, or business management skills (Vesala \& Pyysiainen, 2008). For example, the networking set of skills encompasses the sub-skills of communication, collaboration/team building, strategic thinking, leadership, and opportunity skills. In addition, the skill sets of networking, idea, and strategic thinking are required to serve the purpose of recognising and realising business opportunities. In contrast, the supporting communication skills are "only" related to the ability to communicate in an appropriate oral, written, and physical manner. As a result of these findings, the new model of 'five plus 2' sets of crucial skills for the entrepreneurial success of self-employed fine artists in the arts will be defined and reasonably used in the context of this study.

\section{Research Design and Methodology}

A cross-sectional study was conducted from 15th of January to the 30th of June 2013, including course and module handbooks and other detailed programme specifications for fine art degree programmes in the academic year 2013/14. The analysis reveals the actual situation in the entrepreneurial education of fine art students in the UK and Germany.

In order to gain a deeper understanding of the current educational situation at HEIs in both countries an exploratory and inductive research approach with a survey strategy is taken. This approach is needed because there are hardly any empirical findings in the UK and Germany to explain whether, how and to what extent fine art undergraduates (or undergraduates of other non-business subjects) will be equipped with entrepreneurial skills and therefore be educated on how to make a living in the arts as self-employed fine artists. The study's findings will therefore contribute to the academic literature in this still unrevealed but highly likely growing field of cultural entrepreneurship research.

\subsection{Research Methods}

In order to build up the required database for this comparative study a comprehensive Internet research in combination with various research methods is pursued. The variance of research methods arises firstly as the result of strongly varying opportunities to get access to the course information and secondly for the sake of triangulating the findings. In particular, the review of literature and secondary data, the Internet research, and written enquiries are used as research methods.

\subsection{Analysis Criteria}

The analysis includes the qualitative and quantitative evaluation of educational offerings of entrepreneurial skills for fine art students. The main focus of this study is, however, on the investigation of the regular fine art curricula for undergraduates at the university level at HEIs. The needed course information comprises detailed course structures and programme characteristics. Additionally, in order to illustrate a much broader overview of the educational situation of fine art students post-graduate programmes (Master programmes), existent entrepreneurial and business-related in-house extra-curricular offerings have also been taken into consideration.

In this context, the analysis includes three main steps:

(1) The identification of relevant HEIs that offered fine art degree programmes for undergraduates at university level in the UK and Germany in the academic year 2013/14. Fine art degree programmes encompass, in the context of this study, the single subjects fine art, photography and painting. The entire set of identified accredited HEIs encompasses 134 universities as well as higher education colleges in the UK $\left(\mathrm{N}_{\mathrm{UK}}=134\right)$ and 34 universities and Kunsthochschulen ${ }^{1}$ in

${ }^{1}$ In Germany universities and Kunsthochschulen offer higher education in Fine Art. Their services are quite similar.

However, Kunsthochschulen are focused more on practical experiences than on research. 
Germany $\left(\mathrm{N}_{\mathrm{Ger}}=34\right)$. However, not all of these institutions provided the required data or replied to written enquiries. Therefore, the sample size is $87 \mathrm{HEIs}$, which is in total smaller but nevertheless significant for this study, as illustrated in Figure 1. Seventy-five institutions in the UK $\left(\mathrm{n}_{\mathrm{UK}}=75\right)$ and 12 in Germany $\left(\mathrm{n}_{\mathrm{Ger}}=12\right)$ published the needed data in their course brochures, programme specifications and in their detailed module handbooks or in their answers to written enquiries. The sample is not representative, however, statements on educational trends are possible to make.

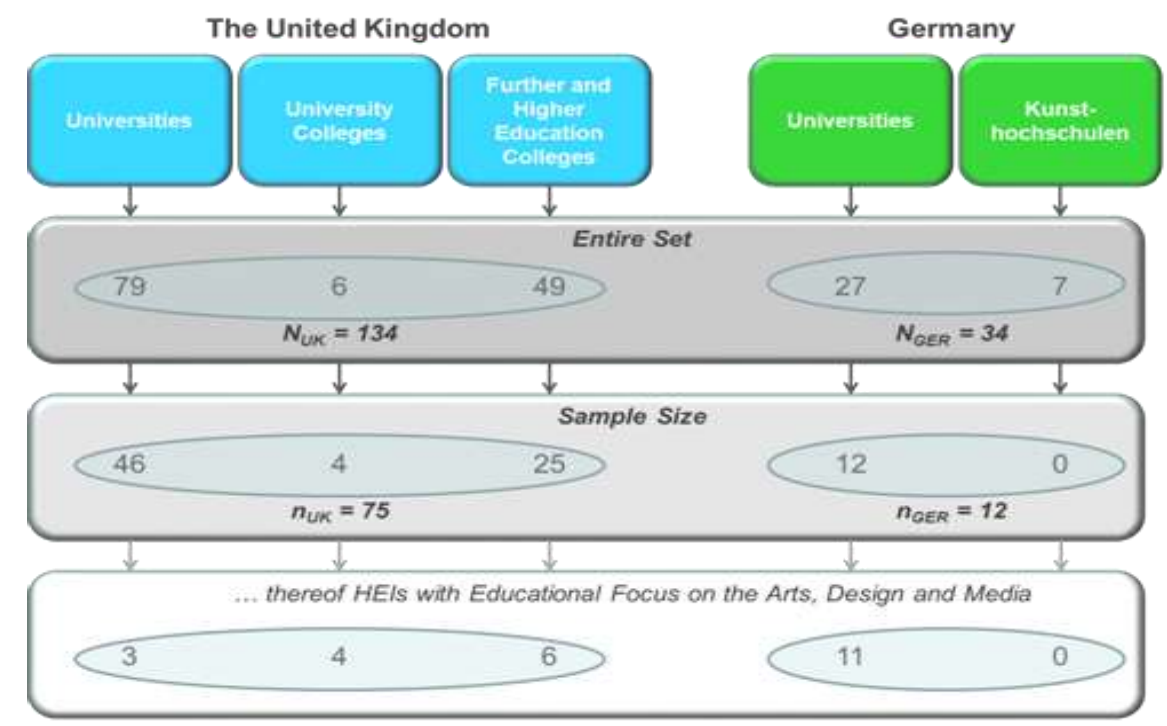

Figure 1. Structure of the Samples, Fine Art Degrees at University Level at HEIs in the UK and Germany, Academic Year 2013/14.

\section{Source: Author}

(2) The analysis of regular fine art undergraduate curricula, post-graduate programmes, and entrepreneurial and business-related extra-curricular courses, offered by the HEIs. Overall, 87 degree programmes for undergraduates, 56 post-graduates programmes, and 45 extra-curricular in-house courses and seminars are reviewed and analysed.

In this context the course data will be converted into measureable educational key performance indicators (KPIs), which are based either on ECTS credit points or workload measured in working hours per average student and illustrated in Table 1. By completing a course, seminar or module a student is awarded with national or standardised European ECTS credit points. Typically, one year of study corresponds to 60 ECTS or 120 UK credit points. Therefore, a three-year Bachelors programme usually has 180 ECTS or 360 UK credit points and a five-year Diploma programme at German HEIs has 300 ECTS credit points. Due to the standardization of the workload in Europe, ECTS credit points are used as a valuation principle for measuring and illustrating the proportions of 'five plus 2' entrepreneurial skills to the total workload of provided fine art courses and programmes within and across both countries. Every ECTS credit point stands hereby for a certain amount of work load, measured in time. In practice one ECTS credit point is equal to 20 hours of student work in the UK (QAA, 2008; Hörig, 2010; Tuning, 2014) and 30 working hours in Germany (Hörig, 2010; Bachelor.de, 2014; Studieninformation Baden-Württemberg, 2014). Because of these inter-country differences in measuring workload in time per one ECTS credit point, the estimated working hours to develop entrepreneurial skills are particularly used as a valuation principle for comparative purposes of the students' average learning effort between both countries.

The use of KPIs enables the creation of a more transparent structure of complex data that, in turn, simplifies the assessment and enhances the comparison of findings among peer HEIs within and across both countries. 
Table 1. Sub-Questions and Derived Key Performance Indicators (KPIs)

\begin{tabular}{|c|c|}
\hline Sub-Questions & Derived KPIs \\
\hline $\begin{array}{l}\text { To what extent were "five plus } 2 \text { " entrepreneurial skills } \\
\text { taught in the regular fine art curriculum of undergraduates? }\end{array}$ & $\begin{array}{l}\text { KPI "Entreprene urial Fitness" } \\
\text { ratio: workload "five plus 2" entrepreneurial skills to total workload of fine art } \\
\text { curriculum (in working hours) }\end{array}$ \\
\hline $\begin{array}{l}\text { To what extent were employability skills taught in the } \\
\text { regular fine art curriculum of undergraduates? }\end{array}$ & $\begin{array}{l}\text { KPI "Employability" } \\
\text { ratio: workload employability skills to total workload of fine art curriculum (in working } \\
\text { hours) }\end{array}$ \\
\hline $\begin{array}{l}\text { To what extent were for fine art students accessible extra- } \\
\text { curricular in-house courses with focus on } \\
\text { entrepreneurship and business management offered? }\end{array}$ & $\begin{array}{l}\text { KPI "Extra-Entre preneurship" } \\
\text { number of internal entrepreneurial and business-related extra-curricular courses per } \\
\text { academic year that are accessible for fine art students }\end{array}$ \\
\hline $\begin{array}{l}\text { Were study visits or work placements compulsory part in } \\
\text { the regular fine art curriculum of undergraduates? }\end{array}$ & $\begin{array}{l}\text { KPI "Compulsory Work Experience" } \\
\text { ratio: workload of compulsory work placements to the total workload of fine art } \\
\text { curriculum (in weeks) }\end{array}$ \\
\hline $\begin{array}{l}\text { Were practicing and self-employed fine artists integrated } \\
\text { as guest lecturers into the regular curriculum of } \\
\text { undergraduates? }\end{array}$ & $\begin{array}{l}\text { KPI "Guest Lecturers" } \\
\text { number of guest lectures in academic year 2013/14 }\end{array}$ \\
\hline $\begin{array}{l}\text { Were practicing and self-employed fine artists integrated } \\
\text { as individual mentors/coaches into the regular fine art } \\
\text { curriculum of undergraduates? }\end{array}$ & $\begin{array}{l}\text { KPI "Mentoring" } \\
\text { number of professional artists working as mentors with undergraduates in academic } \\
\text { year 2013/14 }\end{array}$ \\
\hline
\end{tabular}

\section{Source: Author}

(3) And finally, the interpretation of data and findings.

In order to reliably use the above mentioned KPIs it is necessary to distinguish the three different categories of skills that are taught in the regular fine art curricula: professional skills, transferable employability skills, and entrepreneurial skills. The last category comprises in this study the identified crucial 'five plus 2' skills, as illustrated in Figure 2.

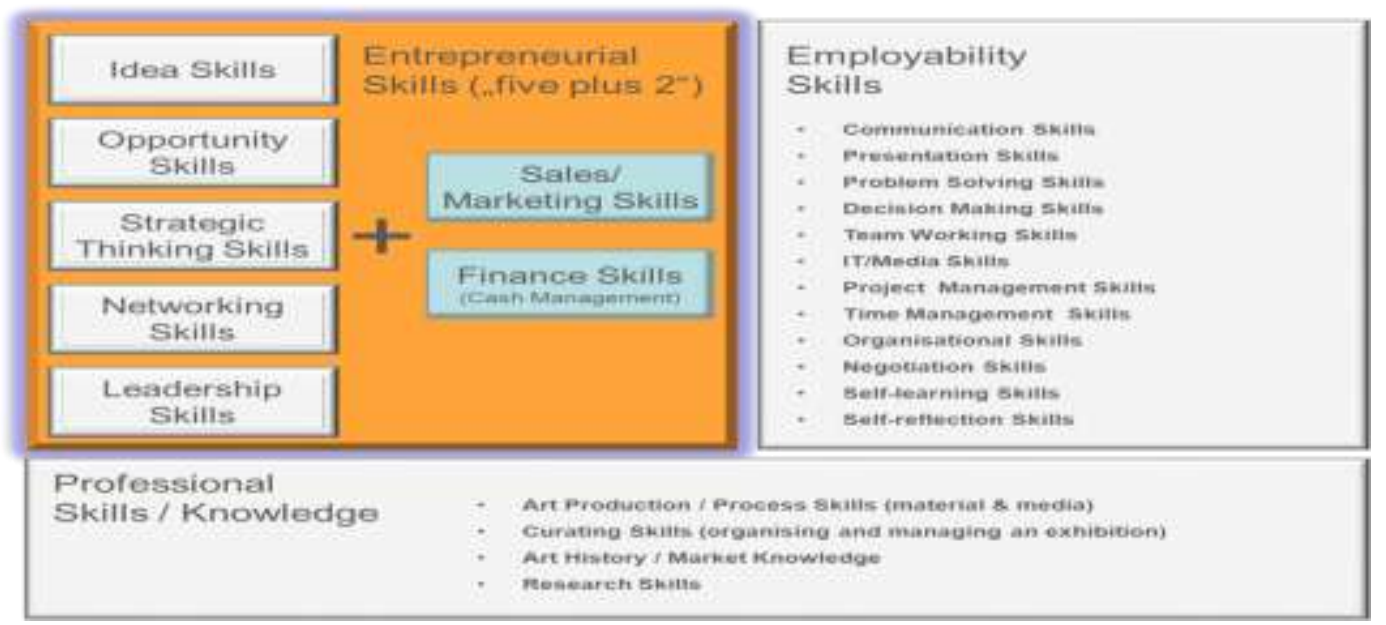

Figure 2. Categories of Skills Taught in the Regular Fine Art Curricula at HEIs,

UK and Germany.

\section{Sources: Author, Fine Art Curricula}

\section{Findings and Interpretation}

\subsection{Key Performance Indicators: "Entrepreneurial Fitness” versus "Employability”}

Both KPIs show to what extent 'five plus 2' entrepreneurial and employability skills are taught in the regular fine art curricula of undergraduates in the academic year 2013/14.

The analysis shows interesting key findings, which are summarised as follows:

- The average proportion of 'five plus 2' entrepreneurial skills in regular fine art curricula was $5 \%$ at HEIs in the UK and less than $2 \%$ at German institutions;

- The average proportion of employability skills in regular fine art curricula was $43 \%$ at UK HEIs and $36 \%$ at HEIs in Germany. 
-Some crucial 'five plus 2' entrepreneurial skills, reasonably required for achieving entrepreneurial success and making a living as self-employed artist, were not taught at all.

Table 2. Results KPI "Entrepreneurial Fitness" and "Employability", Regular Fine Art Curricula, UK and Germany, Academic Year 2013/14.

\begin{tabular}{|c|c|c|c|}
\hline & & UK & Germany \\
\hline (1) & Number of HE Institutions (s ample) & 75 & 12 \\
\hline \multirow[t]{10}{*}{ (2) } & KPI "Entrepreneurial Fitness" & & \\
\hline & (mean workload "five plus 2" entrepreneurial skills, in ECTS credits) & 9.04 & 3.5 \\
\hline & (mean workload "five plus 2 " entrepreneurial skills, in working hours) & 180.8 & 105 \\
\hline & thereof compulsory/optional & $9.04 / 0$ & $3.5 / 0$ \\
\hline & Mean KPI "Entrepreneurial Fitness" (in \%) & & \\
\hline & $\begin{array}{l}\text { (weighted average: sum of individual ratios of "five plus } 2 " \\
\text { entrepreneurial skills in relation to number of HEIs) }\end{array}$ & 5.23 & 1.74 \\
\hline & Min & 1.11 & 0.67 \\
\hline & $\operatorname{Max}$ & 12.5 & 3.33 \\
\hline & Median & 4.44 & 1.61 \\
\hline & Standard Deviation & 2.57 & 0.96 \\
\hline \multirow[t]{6}{*}{ (3) } & KPI "Employability" & & \\
\hline & $\begin{array}{l}\text { Mean KPI "Employability" (in \%) } \\
\text { (weighted average: sum of individual ratios of } \\
\text { employability skills in relation to number of HEIs) }\end{array}$ & 43.22 & 36.35 \\
\hline & Min (compulsory and optional) & 25.00 & 14.59 \\
\hline & Max (compulsory and optional) & 69.44 & 48.33 \\
\hline & Median & 40.42 & 35.02 \\
\hline & Standard Deviation & 11.52 & 9.10 \\
\hline
\end{tabular}

\section{Source: Author, own calculation}

Alongside the development of professional, subject-specific skills the findings show clear evidence that developing the employability of graduates is also a primary aim of fine art students in both countries. Therefore, it is not surprising that the average proportion of the UK-KPI "Employability" to the total workload was, at 43\%, more than eight times higher than the average figure of the KPI "Entrepreneurial Fitness" (Figure 3). In Germany, the gap between both KPIs was considerably larger, with less than $2 \%$ of the studies' total workload scheduled, on average, for teaching crucial entrepreneurial skills (Figure 4).

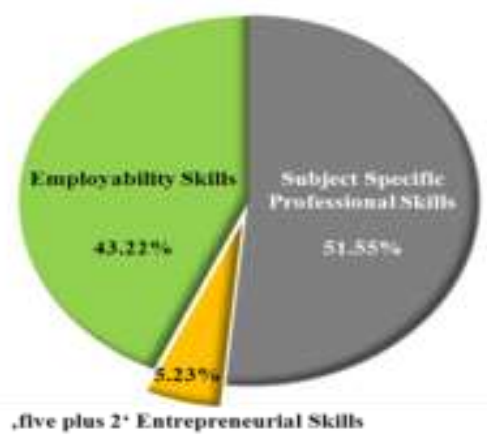

Figure 3. Average Proportions of Skills, Regular Fine Art Curricula for Undergraduates, UK Sample, Academic Year 2013/14.

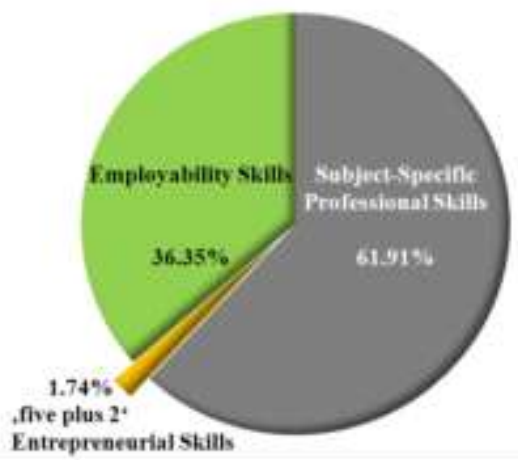

Figure 4. Average Proportions of Skills, Regular Fine Art Curricula for Undergraduates, German Sample, Academic Year 2013/14.

Sources: Author, own calculation 
The analysis of detailed module descriptions and answers to written enquiries basically show that entrepreneurial skills were taught in compulsory modules at all institutions in both samples. This finding can be considered positively in the context of this study. That means that fine art undergraduates were definitely educated in and equipped with some entrepreneurial skills during their studies in the academic year 2013/14, even if only to a minor extent.

Consequently, the question is: "Which of the crucial 'five plus 2' entrepreneurial skills were taught at HEIs in the UK and Germany?" In order to answer this sub-question, the entrepreneurial skills taught were listed and additionally ranked by the number of times each skill was named in the regular fine art curriculum of each HEI. The latter step underlines the entire relevance of these skills in fine art curricula in the UK and Germany. The results of this analysis are illustrated in Figures 5 and 6.

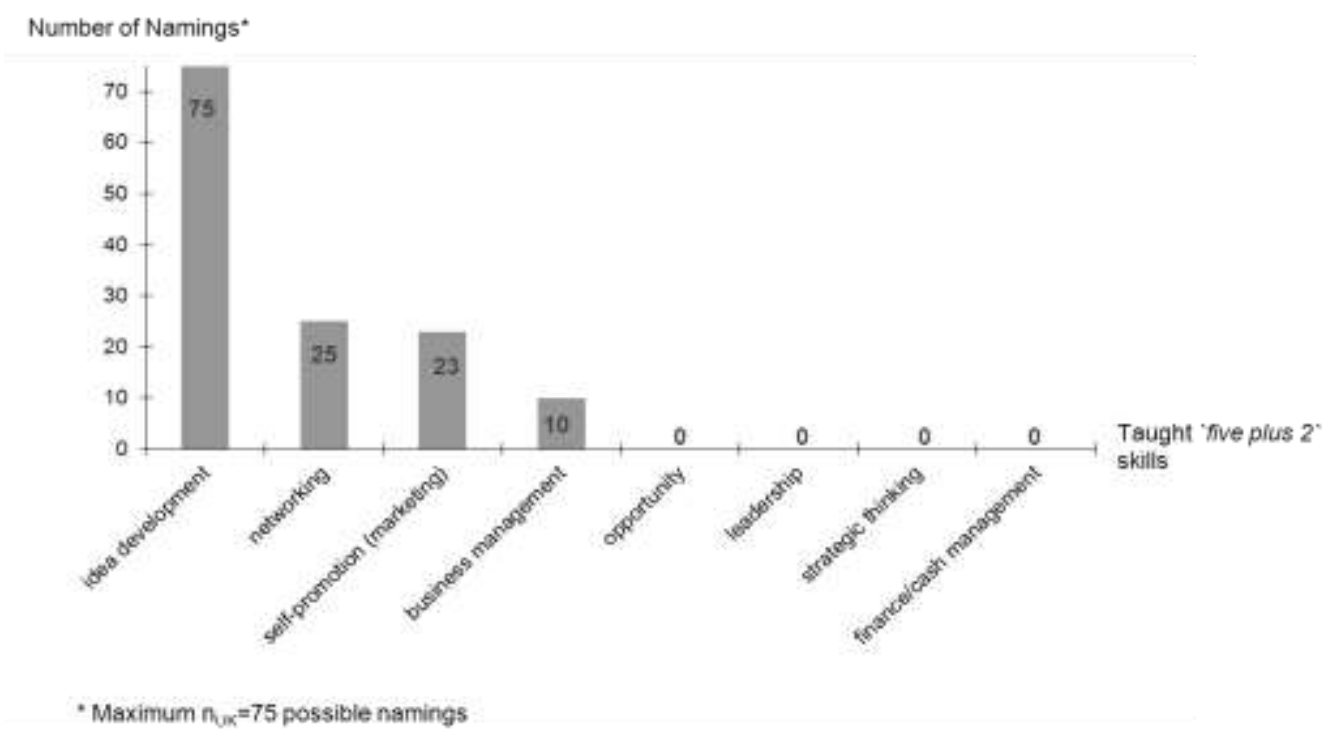

Figure 5. Taught 'Five Plus 2' Entrepreneurial Skills in Regular Fine Art Curricula of Undergraduates, UK Sample, Academic Year 2013/14.

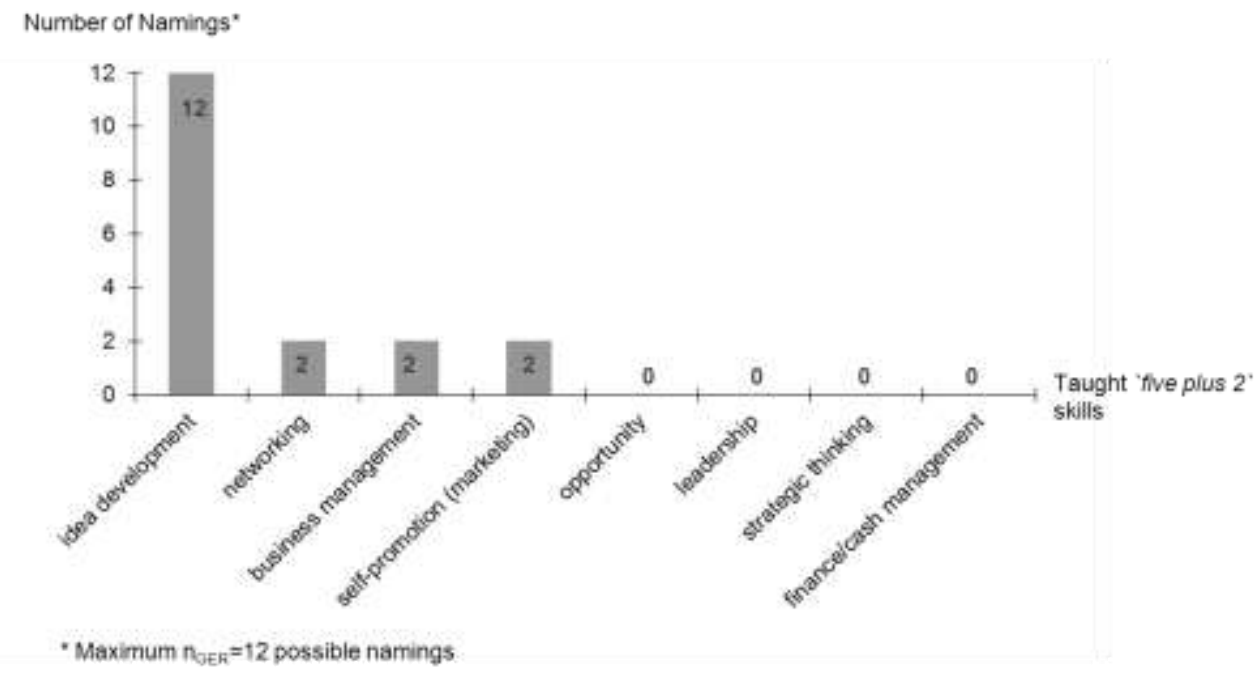

Figure 6. Taught 'Five Plus 2' Entrepreneurial Skills in Regular Fine Art Curricula of Undergraduates, German Sample, Academic Year 2013/14.

\section{Sources: Author, own calculation}

The findings show that only three of the crucial 'five plus 2' entrepreneurial skills were taught in both samples. In addition to the three skill sets of idea, networking, and marketing (sales and promotion) a few skills in the business management disciplines were also taught. These business management skills encompassed, at UK HEIs, funding and acquisition issues, which is the reason why the business management skills were listed as an additional set of skills in these graphs. However, the direct teaching of finance/cash management skills in particular did not take place in both samples as an integrated part of the business management skills. The business management skills at the German institutions were more focused on accounting, funding, and commercial law (intellectual property law) issues. 
The skill with the highest relevance in fine art curricula in both sample groups was the development of an art idea, named by each of the HEIs in both samples. The reasons for the highest-ranking position are obvious. Firstly, fine art education is based on creativity. More than in any other profession, the students need to develop ideas and an art approach for the creation of professional output, namely the individual art portfolio. Secondly, the art approach and idea are considered by the HEIs, alongside artistic talent, as the absolute prerequisite for developing and maintaining an artistic personality with which a successful position in the art market among practicing artists can be established. A successful positioning, in turn, helps to increase the degree of awareness and raise the artist's profile among peer artists, gallerists, art dealers, journalists, critics, and finally by art investors. A successful positioning is therefore needed in order to distinguish oneself from other artists. However, some crucial 'five plus 2' entrepreneurial skills, such as opportunity skills, strategic thinking, leadership, and cash management skills were totally out of consideration at the investigated HEIs of both samples. Instead, the institutions defined their educational focus on employability and subject-specific professional skills.

\subsection{In-House Extra-Curricular Offerings and Post-Graduate Programmes}

The study further investigates whether entrepreneurial and business-related in-house extra-curricular courses were provided, which could help to develop the 'five plus 2' skills. The focus of the investigation is therefore only on in-house offerings because this study will investigate if fine art undergraduates will be equipped with the crucial skills during their fine art studies at HEIs.

The analysis of the sample groups brings the following results to light:

-Forty-one out of the 75 HEIs in the UK (54.67\%) and four out of twelve HEIs in Germany offered entrepreneurial and business-related extra-curricular courses, available for HEI's students and graduates of all departments and subjects;

- These courses were organised and managed centrally either by the HEIs' enterprise and business development teams (incubation services/business school; 36 out of 41 in the UK and 2 out of 4 in Germany) or by the career service departments (5 out of 41 in the UK and 2 out of 4 in Germany). The art departments or faculties have not been involved in the organisation of those courses.

-Explicit courses in entrepreneurship were mainly focused on business venturing, business planning, and venture capital acquisition;

•(Fine) Artists do not normally attend those extra courses;

-Entrepreneurial and business-related extra-curricular courses with a special focus on (fine) artists as target group were not offered;

-The most commonly offered course duration was one day (66\% in the UK and $75 \%$ at German HEIs).

-The one-day courses were mostly free for students and graduates, while courses with durations between three and five days normally had a fee.

-Business-related courses were normally organised as workshops and seminars on a broad range of topics such as finance and funding, (online) marketing, intellectual property law, business management, project management in the creative industries, customer acquisition, managing creativity, business plan writing, self-promotion and concept presentations etc.

- The vast majority of UK HEIs offered indicatively more than ten of those extra-curricular courses in the academic year 2013/14. In Germany, two out of the four universities with extra-curricular offerings provided more than ten courses in the academic year 2013/14.

Although these findings show evidence that fine art undergraduates have (theoretically) attractive opportunities to attend workshops and seminars with entrepreneurial and business-related topics for free, it is not really surprising that these students do not normally attend them. There is reasonable doubt if art students' needs can be adequately addressed by these courses. Three facts need to be considered: Firstly, the fact that these course offerings will simply not be promoted by art faculties or the teaching staff. Secondly, fine art students may have huge difficulties in understanding the business and entrepreneurship language, including the business vocabulary and thinking which will be used in those workshops by the training staff, if they are not already familiar with these subject-specific terms and meanings. As the findings show, entrepreneurial and business-related extra-curricular courses are mostly organised and managed by the in-house enterprise and business development teams, which includes lecturers and graduates in the fields of business administration, entrepreneurship and technology/engineering who are working and studying at the universities' business schools or incubations services. These people normally have a deep understanding of business management-related complex topics and usually use a specialised vocabulary regarding business management thinking as well as case studies from non-art industries to transfer knowledge to the audience. This mixture may result in an incomprehensible 
language for fine artists and challenge the transfer of the presented content into their own professional life. Thirdly, the findings also show a main teaching focus on business venturing, business planning, and venture capital funding. In terms of content, these topics are irrelevant for fine art students' success in the arts.

Besides extra-curricular offerings, a master's degree in Arts Management and Arts Entrepreneurship would be another, post-graduate, alternative for developing entrepreneurial skills at HEIs. The analysis of existent post-graduate master's offerings at the HEIs of both samples produces the following three key results for the academic year 2013/14:

•Every university and university college in the UK (in total 50 HEIs) and every second institution in Germany (in total 6 HEIs) offered master's degree programmes for fine art graduates.

- Three master's programmes at UK HEIs were focused on Entrepreneurship for Creatives, while four programmes had their focus on Arts Management. However, the highest proportion with $86 \%$ or in total 43 master's programmes was in Fine Art (also including Art \& Design and Contemporary Arts). At German HEIs master's programmes were solely offered in Fine Art (Bildende Kunst).

- The offered master's degrees in Entrepreneurship for Creatives and Arts Management were solely taught by the art faculties/departments. A cross-disciplinary master's programme for fine art graduates neither exists in the UK nor at German HEIs.

It is striking - but on the basis of first results not really surprising - that the proportion of offered master's degree programmes with a focus on developing business-related and entrepreneurial knowledge and skills was relatively low. Only seven out of $50 \mathrm{UK}$ universities in the sample created a master's degree programme in art management and entrepreneurship, which will help fine art students to be educated on how to become successfully self-employed. However, the vast majority obviously aim to further improve the subject-specific professional skills.

\subsection{Work Placements}

Work placements and internships give fine art undergraduates the chance to gain important practical experience of the real working world outside of the HEIs studios. Skills are developed through experiential learning (Levy, 2013; Seelig, 2014). While a placement definitely enhances the students' set of skills it also helps them to find out more about working in that industry. In this way work placements and internships offer a very good chance for gaining a deeper understanding about what it means and what it takes to work and, particularly, to make a living in the arts.

In the context of this study, compulsory work placements are of special interest due to two aspects. Firstly, compulsory work placements and internships are a much stronger commitment of HEIs to their students to gain practical experience and develop crucial skills alongside their studio work. Secondly, and more importantly for this study, the time and length of compulsory work placements are clearly regulated by the curriculum. This fact will ease the analysis and comparison of KPIs considerably. Optional work placements are, as the term "option" implies, an opportunity to gain practical experience. Some students may work permanently alongside their studies, and some use this opportunity regularly during their study breaks, while others only work once, and still others do not take advantage of this working opportunity at all. Due to this uncertainty, optional work placements are difficult to capture, especially in the context of this study as KPI. However, the provision of optional work placements in the regular fine art curricula will be taken into account for information purposes.

The analysis of course material and written enquiries produces the following key results that are summarised in Table 3:

-Work placements are an essential element of the regular fine art curricula of undergraduates in the UK and Germany.

- The vast majority ( $71 \%$ or 53 out of 75 HEIs) of work placements were an optional part of the regular curriculum in the UK, while $16 \%$ (in total 12 HEIs) of UK HEIs integrated this practical experience as a compulsory part. Almost every tenth regular fine art curriculum neither integrated compulsory nor optional work placements (Figure 7).

-Every third university in the German sample (in total 4 HEIs) integrated compulsory work placements as an essential part of the curriculum, thereof half of the internships last up to six months. The latter institutions established a practical semester into their fine art curricula. Every second German HEI (in total 6 HEIs), however, did not provide any work placements as valuable opportunity of gaining practical experience at all. 


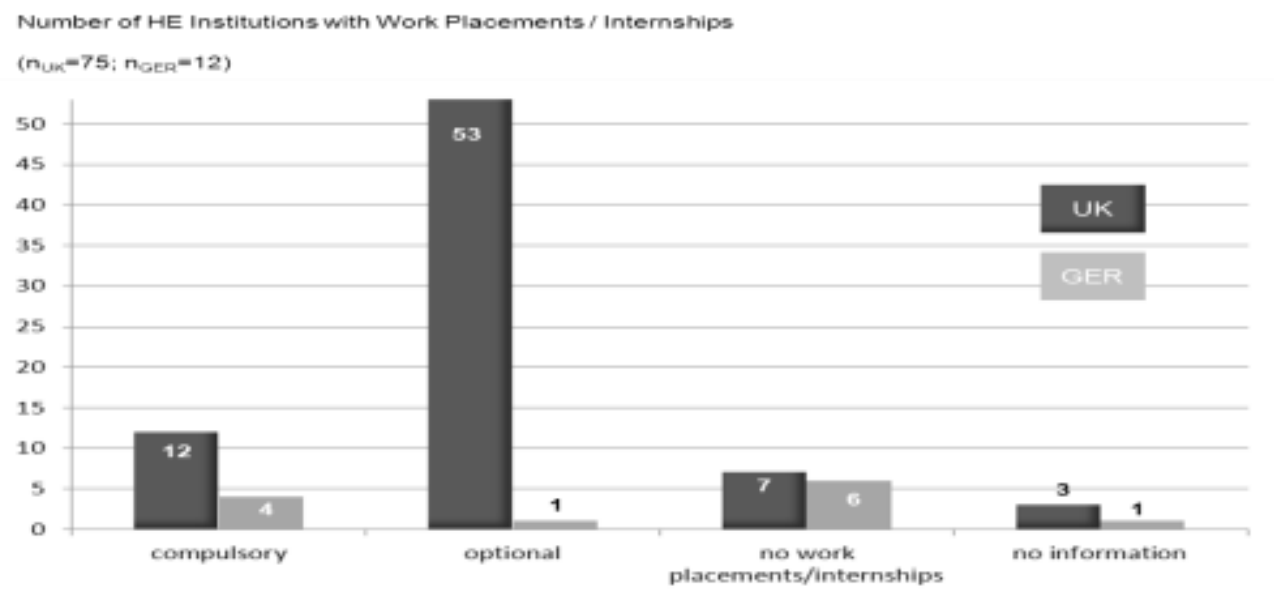

Figure 7. Work Placements / Internships, Regular Fine Art Curricula, UK and Germany,

Academic Year 2013/14.

\section{Source: Author, own calculation}

-The length of time spent in a compulsory work placement varies between two to twelve weeks, only once for the duration of the fine art course, and quite often depends on the art sector and individual employer. Some work placements, particularly the optional ones, are required to be undertaken during holidays. These placements can, therefore, last between one and three months. This relatively long period is also expected in the context of internships, which are a compulsory part of art education at two German institutions (Figure 8).

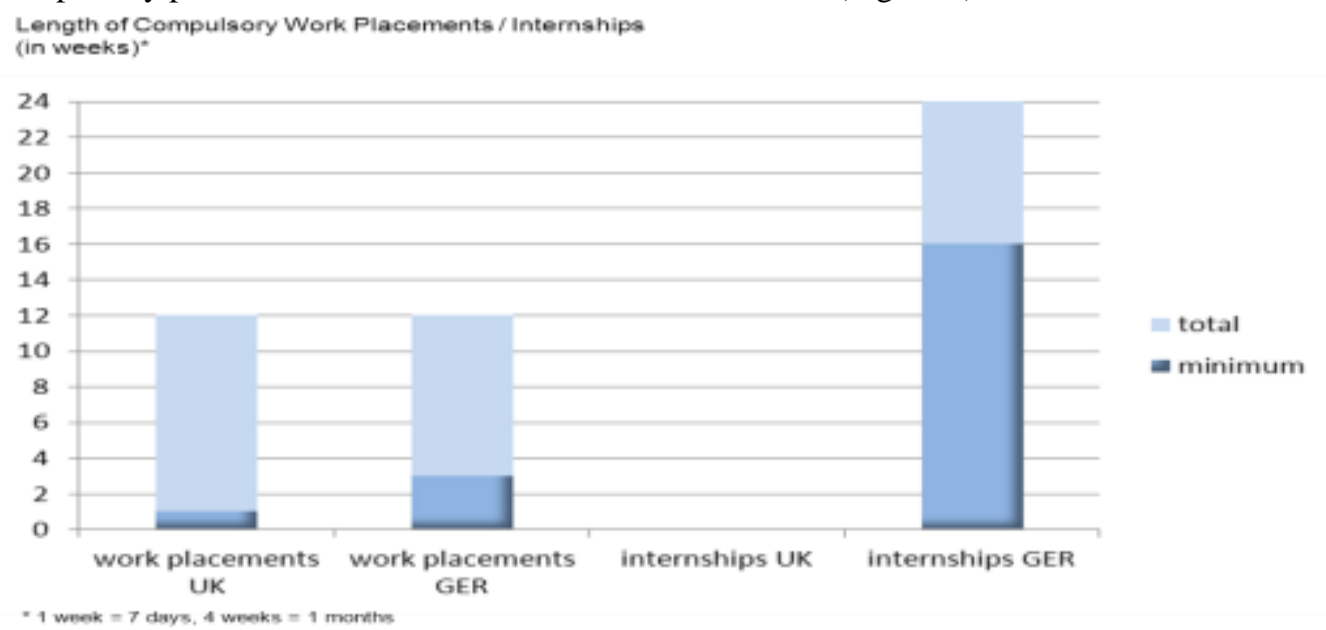

Figure 8. The Length of Compulsory Work Placements / Internships, Regular Fine Art Curricula, UK and Germany, Academic Year 2013/14

\section{Source: Author, own calculation}

As far as the analysis shows, the maximum length of compulsory work placements in both samples were identical with up to twelve weeks or three months. The minimum period of one week occurred only one time in a fine art curriculum in the UK. With three times each, the most frequently recorded lengths of compulsory work placements in the UK sample were two weeks and seven to eight weeks. At German art universities lengths of three and twelve weeks each were mentioned.

The length of work placements can additionally be illustrated as a Key Performance Indicator. The KPI "Compulsory Work Experience" can be calculated as ratio between the number of weeks of a compulsory work placement or internship to the total number of course weeks (fine art course duration). As a result, the KPI shows the proportion as a percentage of compulsory work placements on the total length of the course. In accordance with the academic year structure, an academic year is calculated as 30 weeks without vacations (InternationalStaff, 2013, The University of Edinburgh, 2013; University College London, 2013). Considering this, Table 3 provides an overview of the key findings. 
Table 3. Key Performance Indicator "Compulsory Work Experience", Regular Fine Art Curricula, UK and Germany, Academic Year 2013/14.

\begin{tabular}{|c|c|c|}
\hline & $\mathbf{U K}$ & Germany \\
\hline Number of HEIs (sample) & 75 & 12 \\
\hline $\begin{array}{l}\text { Number of HEIs with compuls ory work placements in regular fine art } \\
\text { curriculum }\end{array}$ & 12 & 4 \\
\hline (in \%) & 16.00 & 33.33 \\
\hline thereof Universities & 9 & 4 \\
\hline thereof University Colleges & 3 & - \\
\hline thereof Further \&Higher Education Colleges & - & - \\
\hline \multicolumn{3}{|l|}{$\begin{array}{l}\text { KPI "Compulsory Work Experience" *) } \\
\text { (in \% of course duration) }\end{array}$} \\
\hline Mean & 7.14 & 11.00 \\
\hline Min & 2.00 & 3.00 \\
\hline $\operatorname{Max}$ & 13.00 & 17.00 \\
\hline Standard Deviation & 3.64 & 5.24 \\
\hline
\end{tabular}

Source: Author, own calculation

Although the sample size is small and not representative, the KPI shows a trend that the proportion of compulsory work placements on the regular fine art curricula was on average slightly higher at German institutions with fine art studies (11\%) than at those in the UK (7.14\%). This result depends enormously on preferred internships in German curricula that last up to six months and were an important part in fine art education at German universities.

Considering the results of this study, there are some reasonable concerns whether fine art undergraduates will really be able to develop entrepreneurial skills during their compulsory work placements:

- Firstly, the proportion of HEIs that integrated compulsory work placements into their regular fine art curriculum is relatively low.

-In addition, particularly the usual 'short term' placements of two to three weeks may reasonably be considered too short of a time to gain the crucial 'five plus 2' entrepreneurial skills. This is especially true for first time placements, where student and employer/individual artist do not know each other or well. Usually, first time "placed" students need to watch the employer/individual artist at work in order to get familiar with processes and behavior first. Then, after a certain period of acclimatisation, the students will be tasked with greater support services and more independently complex activities. Consequently, the ratio between the period of acclimatisation to the length of placement might become an important factor. The higher the ratio the smaller the chances to gain entrepreneurial skills.

- The third point of concern is directly related to the characteristics of crucial entrepreneurial skills. Developing leadership, sales or opportunity and strategic thinking skills normally requires the process of experiential learning through doing. To be honest, it is very unlikely that students, particularly first time 'placed students', will be tasked by the employer or individual artist to sell their art work or services or negotiate contracts and purchase agreements for them. At best, they are allowed to join those occasions.

There might be further points of concern. Work placements only show some small aspects of an artist's real life. The part of handling with entrepreneurial challenges can only be demonstrated by those people that deal with them on a regular basis. Therefore, it is reasonable to presume that the best training environment for fine art students, who wish to pursue a career as self-employed practicing artist, is given by successful, self-employed practicing fine artists themselves. Students could best learn how to 'move and behave' in the real art world. These established artists could act like a mentor or coach. Their valuable experience would be a treasure for any prospective fine artist. In addition, successful artists have normally established a wide-ranging personal network to personalities in- and outside the art industry as well as to investors, and collectors, with whom further success is much easier to achieve. Due to these facts, it is recommended that fine art students, who play with the idea of becoming self-employed art entrepreneurs, should primarily look for placements with successful fine artists or even successful galleries as a 'second best' solution. However, the biggest challenges at this point will be their availability and access for work placements. Applying for a work placement can be as competitive as applying for a permanent job with many organisations and individuals now holding formal interview and/or assessment centre days. So, the difficulty in securing a work placement is a pressing problem.

This recommendation leads to the next KPI. If successful fine artists will not be available for several weeks long 
placements then it could be possible to integrate them as guest lecturers, and, ideally, as mentors into the regular fine art curriculum.

\subsection{Mentoring and Guest Lecturer Programmes}

Inviting practicing and well-established artists as guest lecturers into the classroom can be an invaluable part of fine art students' (entrepreneurial) education. Guest lecturers offer a great opportunity for fine art students to learn other viewpoints within this discipline, to enhance their engagement and enthusiasm in entrepreneurial thinking, to hear about current research and practical applications, and to build a network with professionals.

Mentoring, defined as a process of improving individual knowledge, work efficiency, and, particularly, the way of thinking, is widely acknowledged in entrepreneurship and business incubation as key success factor of professional and, therefore, entrepreneurial development (NBIA, 2010).

Considering this, the key findings of the analysis of course documents and answers to the written enquiries in relation to both programmes can be summarised as follows:

- The majority of HEIs in both samples (65 HEIs in the UK and 10 HEIs in Germany) provided 'guest lecturer' programmes.

- The mean number of guest lectures in the academic year 2013/14 was 18 at UK HEIs. Calculating the academic year with 30 weeks, this figure means one regular guest lecture takes place more than every second week on average. At German institutions the mean was ten visits of guest lecturers per academic year, which means one guest lecture takes place every third week on average.

-Twenty-four HEIs in the UK sample provided guest lectures every week on average, while the maximum frequency at German institutions was 15 visits per academic year, respectively, on average one visit every second week.

- Twenty-four of the investigated HEIs in the UK integrated a mentoring programme into their regular fine art curricula, while this programme was not provided at German institutions at all. On average, between three and four artists worked as mentors on those programmes, mostly organised as a one-year residency programme.

- The integration of graduates (alumni) as mentors into the regular fine art curriculum was possible at 34 institutions or $45 \%$ of all HEIs in the UK. In Germany, none of the investigated institutions integrated alumni-mentors into their fine art curriculum; one institution was, however, in preparation for that.

The findings show evidence that guest lectures were widely integrated into the fine art education process at HEIs in both countries, while mentoring programmes, unfortunately, were established as an important element in the teaching and learning processes at only a few HEIs in the UK. Particularly at German institutions, the importance of mentors, even alumni mentors, was not considered as educational element at all.

\section{Limitations and Conclusions}

\subsection{Limitations}

The variance of research methods for this study arises as the result of strongly varying opportunities to get access to the subject of investigation. For the sake of better triangulating the findings from Internet research, literature review/secondary data, and written enquiries additional survey methods, for example, questionnaire surveys among members of the teaching staff and fine art undergraduates as well as interviews with graduated fine artists and experts in the fields of entrepreneurship and arts should be applied.

Furthermore, the selected cross-sectional approach was more a result of time restrictions than of scientific conviction. This approach only offers a snapshot of a single moment in time and will not consider the development of fine art curricula and fine art students' entrepreneurial skill set before and after the research period of the 2013/14 academic year. Therefore, it is and will remain unknown if changes in the regular fine art curricula towards more entrepreneurship and market orientation had a positive effect on fine art graduates' later entrepreneurial success. The cross-sectional approach cannot recognise cause-and-effect relationships. In contrast, the benefit of a longitudinal study is that those developments and changes in the skill set of fine art graduates as well as relationships between variables such as the aforementioned educational KPIs can be detected over time.

However, due to their quantitative nature, KPIs normally lack the consideration of qualitative issues. They break down substantial data to comparative figures without any focus on qualitative aspects. For example, the length of compulsory work placements can "only" address a quantitative dimension. It shows how long or to what extent students will be able to work in an organisational environment to gain practical experience. However, this KPI cannot explain if a work placement will actually be adequate to gain specific entrepreneurial skills and practical experience. It cannot provide information about the educational quality and what skills will be developed because this would prerequisite the exact 
knowledge about the tasks and challenges a "placed" student will meet. In this context, it is therefore reasonable to link the quantitative dimension of KPIs with the qualitative dimension by using strategic management tools such as the Balanced Scorecard (BSC).

\subsection{Conclusions}

The analyses of regular fine art curricula for undergraduates, entrepreneurial and business-related in-house extra-curricular training offerings, and post-graduate programmes at HEIs in the UK and Germany were conducted with the help of various KPIs. Clear evidence is shown that fine art students will not be sufficiently prepared for their most chosen career path of self-employment, neither at UK nor at German HEIs due to several serious reasons: Firstly, some of the crucial 'five plus 2' entrepreneurial skills, needed to develop, establish, and run a commercial art concept or business, such as strategic thinking (planning) skills, skills to recognize and realize opportunities, leadership skills, and finance/cash management skills are completely missing in the regular fine art curricula. Secondly, those 'five plus 2' entrepreneurial skills that are integrated in the curriculum, namely the idea development skills, networking skills, and self-promoting skills were only taught to a very small extent. The average proportions of these entrepreneurial skills on the total workload of the fine art curricula were only 5\% at UK (or 9 ECTS credit points) and less than 2\% at German institutions (or 3.5 ECTS credit points). In terms of working hours these proportions mean that a fine art undergraduate at an UK HEIs is required to develop these entrepreneurial skills in 180 of in total 3,600 working hours on average, while a fine art student at a German institution would only have 105 working hours time for developing the same three skills. It should be obvious that these time periods are insufficient, particularly when considering the fact that these skills are sets of skills, including other skills. In this short period of time an average fine art student will hardly be able to develop the skills to create a unique and distinguishing art idea, acquire gallerists or consumers and audiences as 'interested followers' or networking partners, and negotiate purchase prices, delivery or funding conditions in order to make a living in the arts. Instead, fine art students will rather be equipped with professional and employability skills than with entrepreneurial ones.

In addition, findings from the analysis of entrepreneurial extra-curricular offerings show that they are mainly organised and managed by the HEIs' business schools, enterprise centres, or business incubation hubs. This suggests that fine art students will not be addressed adequately. This assumption is reasonable when considering the centres' confirmations that fine artists do not attend to their entrepreneurial courses. Either fine art students simply do not know about these offerings and are not informed by their teaching staff, career centres and HEIs top management, what is still to be investigated, or they do not see the benefits of attending those courses because they might not be recognised as relevant for the entrepreneurial and daily challenges of fine artists due to their traditional focus on business venturing, business planning, and venture capital acquisition. At this point it also needs to be noted that in business courses a vocabulary is likely used that is not appropriate for non-economists. Therefore, specific and bespoken entrepreneurial trainings with an adequate language are mostly needed and recommended for fine artists in order to equip them with the relevant 'five plus 2' skills that are needed to make a living in the arts. Those trainings can be organised at the HEIs either by the art departments, maybe in association with the HEIs business schools or by a university art incubator. Art incubators have a similar purpose to business incubators. They are designed to provide support services, entrepreneurial education, low-cost financing, grants, promotion activities, and mentorship that enable (fine) art students to create their own art business successfully. Art incubators could be organised physically or virtually as an open network of specialised skill providers (Thom, 2011).

\section{References}

Abbing, H. (1999). Why are Artists Poor? The Exceptional Economy of the Arts. Amsterdam University Press

Artists Interaction and Representation (AIR). (2011). Big Artists Survey 2011 - The results. Retrieved from https://www.a-n.co.uk/air/big-artists-survey-2011-the-results-1

Arts Council England. (2011). Review of the Arts Council's Strategic Framework. Retrieved from http://www.artscouncil.org.uk

Bachelor.de. (2014). ECTS-System. Retrieved from http://www.bachelor.de/ects-system.htm

Baines, D., \& Kennedy, C. (2010). An Education For Independence. Should entrepreneurial skills be an essential part of the journalist's toolbox? Journalism Practice, 4(1), 1-7.

Bundesverband Bildender Künstlerinnen und Künstler e.V. (BBK). (2011). Die wirtschaftliche und soziale Situation Bildender Künstlerinnen und Künstler. Ergebnisse BBK Umfrage 2011 [The economic and social situation of fine artists: The results of the BBK survey 2011] Berlin: Bundesverband Bildender Künstlerinnen und Künstler e.V.

Beckman, G. D. (ed). (2011). Disciplining the Arts: Teaching Entrepreneurship in Context. Lanham: Rowman \& Littlefield Education 
Bauer, C., Viola. K., \& Strauss, C. (2011). Management Skills for Artists: 'Learning by Doing'? International Journal of Cultural Policy, 17, 626-644. http://dx.doi.org/10.1080/10286632.2010.531716

Centre for Economics and Business Research Ltd. (CEBR). (2013). The Contribution of the Arts and Culture to the National Economy. An analysis of the macroeconomic contribution of the arts and culture and of some of their indirect contributions through spillover effects felt in the wider economy. Retrieved from http://www.artscouncil.org.uk/media/uploads/pdf/CEBR_economic-report-web-version-0513.pdf

Cobb, P., Ball, S., \& Hogan, F. (eds.). (2011). The Profitable Artist. A Handbook for all Artists in the Performing, Literary, and Visual Arts. New York: Allworth Press

de Monthoux, P. G. (2004). The Art Firm: Aesthetic Management and Metaphysical Marketing. Standford: Standford University Press.

DeTienne, D. R., \& Chandler, G. N. (2004). Opportunity Identification and Its Role in the Entrepreneurial Classroom: A Pedagogical Approach and Empirical Test. Academy of Management Learning and Education, 3, 242-257. http://dx.doi.org/10.5465/AMLE.2004.14242103

de Wolf, P., \& Schoorlemmer, H. (eds.). (2007). Exploring the Significance of Entrepreneurship in Agriculture. Research Institute of Organic Agriculture.

Faltin, G. (2001). Creating a Culture of Innovative Entrepreneurship. Journal of International Business and Economy, 123-140.

Faltin, G. (2007). Erfolgreich gründen: Der Unternehmer als Künstler und Komponist. [Being successful in starting up a business - The entrepreneur as artist and composer] Berlin: DIHK Deutscher Industrie- und Handelskammertag.

Faltin, G. (2008). Kopf schlägt Kapital: Die ganz andere Art, ein Unternehmen zu gründen. Von der Lust, ein Entrepreneur zu sein. [Go with your Head - An unusual way to start a business. About the passion of being an entrepreneur] - München: Carl Hanser Verlag. http://dx.doi.org/10.3139/9783446418059

Frank, R. H., \& Cook, P. J. (1996). The Winner-Takes-All Society. Why the few at the top get so much more than the rest of us. New York: Penguin Books

Gibb, A. (1998). Entrepreneurial Core Capacities, Competitiveness and Management Development in the $21^{\text {st }}$ Century. Research Paper, Durham University Business School, 14.

Gibb, A. (2005). Towards the Entrepreneurial University. Entrepreneurship Education as a Lever for Change. National Council for Graduate Entrepreneurship Policy paper (NCGE). Retrieved from http://www.ncee.org.uk/publication/towards_the_entrepreneurial_university.pdf

Hörig, M. (2010). Credit systems and Learning outcomes in Europe. Presentation European University Association, 15. April 2010. Retrieved May 16, 2014 from http://www.eua.be/fileadmin/user_upload/files/newsletter2010/MiH_ECTS_LO_Asem_berlin_15042010_rev.pdf

International Staff. (2014). Academic Year. Retrieved from http://www.internationalstaff.ac.uk/education/academic-year/

Landwehr, S. (2005). Know-how-Management bei der Gründung innovativer Unternehmen. [The know-how management of innovative business start-ups] (Doctoral dissertation). Erlangen: Universität Erlangen-Nürnberg. http://dx.doi.org/10.1007/978-3-322-82052-5

NBIA National Business Incubation Association. (2010). Best Practices in Action: Guidelines for Implementing First-Class Business Incubation Programs ( $2^{\text {nd }}$ ed.). Athens: NBIA Publications.

Oberschachtsiek, D. (2008). Founders' Experience and Self-employment Duration: The importance of being a 'Jack-of-all-trades'; an analysis based on competing risks. Institute for Employment Research, 40, 1-27.

Quality Assurance Agency for Higher Education (QAA). (2008). Higher Education Credit Framework for England: Guidance on Academic Credit Arrangements in Higher Education in England. Retrieved from http://www.qaa.ac.uk/publications/informationandguidance/documents/creditframework.pdf

Rudmann, C. (2008). Entrepreneurial Skills and their Role in Enhancing the Relative Independence of Farmers. Results and Recommendations from the Research Project Developing Entrepreneurial Skills of Farmers. Research Institute of Organic Agriculture.

Schumpeter, J. A. (2003). The Theory of Economic Development. In: J.G. Backhaus (Ed.), Joseph Alois Schumpeter: Entrepreneurship, Style And Vision (pp.61-116). Boston: Kluwer. http://dx.doi.org/10.1007/0-306-48082-4_3 
Seelig, T., \& Peña, M. (2014). Experiential Learning Essential to Entrepreneurship Education at Stanford. Stanford Technology Ventures Program. Retrieved May 21, 2014 from http://stvp.stanford.edu/experiential-learning-essential-to-entrepreneurship-education-at-stanford/

Smith, E. E., \& Perks, S. (2006). Training Interventions Needed for Developing Black Micro-entrepreneurial Skills in the Informal Sector: A Qualitative Perspective. Journal of Human Resource Management, 4, 17-26.

Statistisches Bundesamt (destatis). (2010). Selbständige in Deutschland. Ergebnisse des Mikrozensus 2008. Wirtschaft und Statistik 12/2009 [Self-employed Persons in Germany: The Results of the Microcensus 2008. Economics and Statistics 12/2009], (pp. 1204-1217). Retrieved from

https://www.destatis.de/DE/Publikationen/WirtschaftStatistik/Arbeitsmarkt/SelbststaendigeDeutschland.pdf?_blo $\mathrm{b}=$ publicationFile

Stokes, D., \& Wilson, N. (2010). Small Business Management and Entrepreneurship (6 ${ }^{\text {th }}$ ed.) Andover: Cengage Learning EMEA.

Studies information Baden-Württemberg. (2014). Leistungspunkte (ECTS-Punkte) [Credit Points]. Retrieved from https://www.studieninfo-bw.de/studieren/bachelormaster/leistungspunkte_ects_punkte/

Swedberg, R. (2006). The Cultural Entrepreneur and the Creative Industries: Beginning in Vienna. Journal of Cultural Economics, 30, 243-261. http://dx.doi.org/10.1007/s10824-006-9016-5

The University of Edinburgh. (2013). Academic Year Structure. Retrieved from http://www.ed.ac.uk/news/semester-dates/structure

Thom, M. (2011). Business Incubation - How to Manage the Know-how Transfer (master's thesis). München: GRIN Verlag

Thornhill, S., \& Amit, R. (2003). Learning About Failure: Bankruptcy, Firm Age, and the Resource-Based View. Organization Science, 14, 497-509. http://dx.doi.org/10.1287/orsc.14.5.497.16761

Tuning Educational Structures in Europe. (2014). Educational structures, Learning outcomes, Workload and the Calculation of ECTS credits. Retrieved May 16, 2014 from

http://www.unideusto.org/tuningeu/workload-a-ects/177.html

University College London. (2013). Academic Year 2013/14 - UCL. Retrieved December 21, 2013 from http://www.ucl.ac.uk/estates/roombooking/calendar/1314.pdf

Vesala, K. M., \& Pyysiäinen, J. (2008). Understanding Entrepreneurial Skills in the Farm Context. Final Report on the main study of the EU-funded project Developing Entrepreneurial Skills of Farmers.

Weinhold, K. (2005). Selbstmanagement im Kunstbetrieb. Handbuch für Kunstschaffende [Self-Management in the Arts. A Handbook for Artists] Bielefeld: transcript Verlag

\section{$(\mathrm{cc})$ EY}

This work is licensed under a Creative Commons Attribution 3.0 License. 